\title{
Crafting a Sustainable Corporate Performance: The Value of Corporate Conscience
}

\author{
J Kamwachale Khomba ${ }^{1}$, Rabiya Hanif ${ }^{2}$, Ella C Kangaude-Ulaya ${ }^{3} \&$ Kizito Kanyoma ${ }^{3}$ \\ ${ }^{1}$ Department of Management Studies, University of Malawi, Blantyre 3, Malawi \\ 2 Department of Accountancy, University of Malawi, Blantyre 3, Malawi \\ ${ }^{3}$ Department of Business Administration, University of Malawi, Blantyre 3, Malawi \\ Correspondence: J Kamwachale Khomba; PhD, FCMA, Associate Professor, Department of Management Studies, \\ University of Malawi, Private Bag 303, Blantyre 3, Malawi. E-mail: jkkhomba@gmail.com, jkkhomba@poly.ac.mw
}

Received: April 6, 2013

doi:10.5430/jms.v4n3p94
Accepted: May 14, 2013

Online Published: August 1, 2013

URL: http://dx.doi.org/10.5430/jms.v4n3p94

\begin{abstract}
It is common knowledge that an organisation cannot operate in isolation without the critical roles that various stakeholders play in influencing organisational operations and ultimate corporate performance. Thus, stakeholders that are interdependent have to be rewarded based on their respective efforts in promoting and creating organisational wealth in different capacities. This study aimed at ascertaining the extent of corporate conscience phenomenon as on how body corporates in Malawi tackle and distribute wealth to their different stakeholders who are actively involved in the creation of such an organisational wealth. The study findings reveal that most business executives in Malawi recognise that being a body corporate with a conscience is a recipe for success of their current and future operations and the ultimate sustainable corporate performance. It is anticipated that the study results will improve the perception of business executives towards corporate conscience as well as transform the approaches in academic and business research programmes.
\end{abstract}

Keywords: corporate conscience, corporate performance, corporate social responsibility, Malawi, shareholder, stakeholder, sustainability, value

\section{Introduction}

Among scholars and corporate managers, there has been a growing debate on how companies should treat their stakeholders with regard to the distribution of wealth that is created by the stakeholders themselves. There have been cases where companies have shown total neglect of some critical stakeholders in order to please other stakeholders, such as shareholders (Stovall et al., 2004). Such an approach encourages managers to focus their corporate strategies on the maximisation of profits, which can encourage short-termism and consequently become morally harmful to other stakeholders as well. For instance, under the shareholder-centred approach, other stakeholders, such as employees, customers, the community, and the natural environment, are usually ignored and their interests are often virtually disregarded (Khomba, 2011). Thus, corporate conscience focuses on how the organisational wealth that is created is allocated and distributed to those who were involved in the process of value creation, directly or indirectly. It is not enough, it has been felt, for a body corporate, to just operate within the law but going beyond and addressing the stakeholders with a conscience.

Corporate conscience highlights the need for the organisational wealth that is created to be shared equitably amongst all the stakeholders that are involved in all the value creation processes that are intertwined and interdependent in nature (Capra \& Pauli, 1995, Stead \& Stead, 2004). Therefore, every corporation must have a conscience regarding its obligation to share the value created or resources with different stakeholders in the most equitable and ethical manner (Carroll, 1979; Morgan et al., 2009; Rasche \& Esser, 2006). Contributions to corporate social responsibility in local communities, and the protection and enhancement of the natural environment are clearly areas where organisations can show their corporate citizenship that should come from their inner corporate conscience. 


\section{Research Aim and Objectives}

Local managers are excited at posting massive profits for their companies' shareholders without regard as to who painfully create and pay for those profits. Therefore, this study aimed at establishing the dimension of corporate conscience among companies where it is stressed that it is not only just satisfying the corporate responsibility as a manager in terms of shareholder wealth maximisation but also having that conscience, as a corporation, on rewarding contributions that different stakeholders make towards the corporate environment. Within this thinking, wealth generated by the body corporate is supposed to trickle down to various stakeholders that were directly or indirectly engaged during the complex wealth creation processes of the company.

Specifically, the article gives the background to the general issues revolving around stakeholder involvement in wealth creation, outlines research design and methodologies that were used during the study, reports on research findings and finally makes conclusions and recommendations.

\section{Corporate Conscience: Shareholder Satisfaction or Stakeholder Value?}

Contemporary managers have a duty to sustain future operations of their corporations where focus has to be given to all their stakeholders, apart from just fulfilling their economic objectives. This is relatively a new phenomenon in business circles as many corporations tend to focus their attention on the allocation of corporate wealth to solely shareholders through the maxim of "maximisation of shareholders' wealth" (Friedman, 1993). Thus, the shareholder-centred approach encourages managers to focus their corporate strategies on the maximisation of profits, which can encourage short-termism and consequently become morally harmful to other stakeholders as well (Stovall et al., 2004).

Under the shareholder-centred approach, other stakeholders, such as employees, customers, the community, and the natural environment, are usually ignored and their interests are often virtually disregarded. Direct contributions by these groups to the corporation are regarded either as an input that makes up a product or service, or perhaps as an externality that falls outside the realm of economic and business language. Some studies have revealed that the optimisation of the social welfare of communities is inconsistent with the pursuit of corporate profits exclusively to maximise shareholders' self-interest (Downs in Stovall et al., 2004). For example, the pursuit of profit maximisation can lead to company layoffs. Such layoffs, motivated by profit maximisation objectives, have long-term detrimental effects on employees, their families and also local communities. Additionally, such layoffs often lead to significant deficiencies in a company's ability to maintain long-term profits for shareholders (Chilosi, 2012).

The shareholder-centred approach also violates the very reason for corporate existence and the principle of its interconnectedness with its environment. There are broader motivations for corporate management systems (Drucker, 1993). A business has to be managed by balancing the interests of different constituencies, each with a genuine stake in the business. However, this balanced approach to corporate governance has been distorted by the emphasis on maximisation of shareholders' wealth, forcing firms to focus on short-term activities. Notably, the exclusive attention paid to the needs of shareholders may alienate the very same stakeholders upon which the business operationally and strategically depends. However, the maximisation of shareholders wealth maxim retains popularity in business circles and academia as the primary objective of any company.

It should be clear that there are many factors that have an impact on the overall performance of an organisation as well. Such factors include society (the local community) and the natural environment (Aaron, 2012; Stead \& Stead, 2004). To sustain current operations for future generations, organisations need to create the potential to maintain social well-being, which depends on the well-being of the natural environment, in the long run. Thus, organisations must have a conscience regarding their obligation to be responsible in the proper use of natural resources.

Many corporations, especially large ones, have not been able to fulfil their corporate governance requirements when it comes to their corporate social responsibility (Bendixen et al., 2007). Corporations have instead oppressively abused employees and other stakeholders in many ways. For instance, many multinational companies are making abnormal profits at the expense of the local communities and the natural environment. Such malpractices jeopardise stakeholder co-existence and the sustainability of future business and reflect lack of corporate conscience.

Currently, there is a lack of accountability systems for corporate management that considers and incorporates the interests of various stakeholders, especially those from society and the natural environment. Kelly (2001) discusses several efforts that can help to revolutionise the current model for corporate governance to include multiple stakeholders, including the preparation of employee income statements, a company's people-asset-productivity 
measures, a community income statement, and calls for expanding both voluntary and statutory corporate social disclosure as is stipulated in the King III Report (Institute of Directors in Southern Africa, 2009).

The King III Report acknowledges the importance of an integrated reporting system in that "reporting should be integrated across all areas of performance ... and should include reporting on economic, social and environmental issues" (Institute of Directors in Southern Africa, 2009:109). The inclusion of three parameters - economic, social and environmental - is consistent with the triple bottom line reporting requirement that corporations need to display a conscience in respect of social and environmental sustainability as well. Consideration of future generations is vital in business ethics and corporate governance.

The debate on stakeholder treatment by corporations is foundational to the survival of the modern business environment. Within the framework of corporate governance, there should be "corporate conscience" that is based on people's rights, morals and a sense of justice (Tsuno, 2003). In his seminal contribution, The Theory of Moral Sentiments, Smith (1790) maintains that an innate sense of being able to see others' interests allows individuals, and ultimately societies, to develop concepts such as benevolence, altruism and even justice. Thus, the actions of managers should be governed by the actions of consumers, labourers, suppliers and people from the public sector, and that corporate power should be exercised in line with public consensus. This line of argument can be seen as a true forerunner to the concept of corporate governance and business ethics (Akomea \&Adusei, 2013; Nakano, 2007).

\section{Research Methodology}

The study was conducted through primary research using structured questionnaire. The researchers followed basic procedures that are employed when developing the Likert scale questionnaire to measure different perceptions of business executives from the commercial sectors of Malawi. The formulated statements on the structured questionnaire were based on procedures recommended by Saunders et al. (2009). The main steps that were followed when formulating the questionnaire included the identification and generation of identification of stakeholders within an African context, perspectives surrounding stakeholder treatment towards wealth distributions, careful review of literature on the topical area, a review of similar questionnaires that were used in prior surveys, and insights gained from an examination of latest information gathered through the internet, newspapers, magazines, TV and radio broadcastings. All these culminated into the formulation of the attitudinal statements that represented main variables of the study as summarised in Table 1.

\subsection{Data Collection}

Empirical data were collected by means of a national survey. The results were used for an empirical analysis of the research findings. A structured questionnaire was designed, guided by the research problem and research objective. The questionnaire focused on variable statements that would evaluate stakeholder value rankings by different organisations in Malawi.

\subsection{Questionnaire Structure}

To make the questionnaires user-friendly, the researchers formulated statements whose response would use nominal settings (Middle/Senior Management, Yes/No), ordinal settings such as the rank orders, and interval settings based on the Likert-style rating scales with the rankings signifying the degree of agreement ranging from a scale of " 1 " referring to "Strongly Disagree" to a scale of " 5 " referring to "Strongly Agree" on a five-point rating scale of the structured questionnaire. A five-point scale was used to assess validity as to the extent of agreement on each statement.

In Likert scales, it is assumed that all participants will perceive "Strongly Agree" as expressing greatest favour or agreement towards the attitude statements than "Somehow Agree" and "Strongly Disagree" (Babbie and Mouton, 2007; Saunders et al., 2009; Welman et al., 2005). The same order of response categories was maintained so as not to confuse respondents, as recommended by Dillman (2000). Business executives were asked to rate their responses on the continuum scale that they were given. The questionnaire also assisted in the formulation of an objective and scientific report of the study findings.

\subsection{Sampling}

The structured questionnaire was administered in both hard copy and an electronic format. Electronic questionnaires were emailed to potential respondents and the hard copy versions were posted to the respondents and then these were followed up for any feedback. Reminder telephone calls were made and e-mails were sent after every two weeks for three months of the questionnaire survey. 
Large and medium companies were randomly selected from those that are registered with the Registrar of Companies or Malawi Stock Exchange. Researchers also used a list of companies from the Malawi Confederation of Chamber of Commerce and Industry (MCCCI) which represents the private sector of Malawi. Finally, the researchers also used companies' list from the Malawi telephone directory that is prepared by the Malawi Telecommunications Limited (MTL) - this was appropriate especially for details of the medium-sized companies.

\subsection{Sampling Adequacy}

During data collection, a total of 680 questionnaires were dispatched to various organisations from the commercial sector in Malawi. Out of the 680 questionnaires, 419 responded to the questionnaire giving a final response rate of $61.6 \%$. The sampling statistics show that the Kaiser-Meyer-Oklin (KMO) measure of sampling adequacy is 0.830 which is of a great value for verification of sampling adequacy for the analysis, according to Field (2009). Thus, the above analysis confirms adequacy of the sample for conclusive results (according to Chenhall, 2005; Field, 2009; Hanafizadeh and Sorousha, 2008).

\subsection{Data Reliability and Validity}

Data reliability as a measure of internal consistency of the data constructs was determined by means of the Cronbach alpha $(\alpha)$ - an $\alpha$ coefficient above 0.7 is considered reliable (Bryman and Bell, 2007; Costello and Osborne, 2005; Field 2009). In this study, the overall $\alpha$ coefficient was $\alpha=0.905$, which suggests that the internal consistency of the data constructs was excellent. Further analysis of Cronbach's alpha coefficients of the Scale if item deleted gives values that

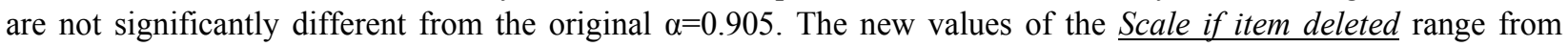
$\alpha=0.901$ to $\alpha=0.909$ signifying that the questionnaire is reliable and that the deletion of any variable cannot significantly affect the original Cronbach's alpha coefficient of $\alpha=0.905$.

In terms of data validity, researchers were careful in sampling the targeted population. Though randomly done, the questionnaire was targeted at large and medium organisations by focussing on business executives at senior management, middle management and other business executives that include the board members. Such business executives include the chief executive officers (CEOs), chief financial officers (CFOs), financial managers, management accountants, and company secretaries who are conversant with issues raised under the study; hence maintaining homogeneity of the sample.

The statistics indicate that the Bartlett test of sphericity $\mathrm{X}^{2}(1427)=11591.73, \mathrm{p}<0.001$ was significant for all factors indicating that we can be confident that multicolinearity does not exist under these survey data according to Field (2009). Thus, the Bartlett's test of sphericity $\mathrm{X}^{2}(1427)=11591.73, \mathrm{p}<0.001$ also signifies that the study results are valid for any conclusive analysis and discussions.

\section{Analysis and Discussion of Research Results}

Ratings on each statement were done through univariate analysis by using individual rating statistics and frequency tables. Overall, the analysis shows that there were varied responses from participants regarding the extent of their agreement on each of the questionnaire statements. This section reports on the study results and analysis of ratings on the questionnaire statements.

\section{Statement 1. Recognition of the interdependence of relationships of stakeholders}

There seems to be a general understanding that an organisation can succeed only if all stakeholders are recognised as interdependent members of and contributors of one team. All the respondents agreed (45.1\% "Agree", 46.1\% "Strongly Agree" and 8.8\% "Somehow Agree") with this sentiment. The analysis thus indicates that business executives recognise the interdependence and value of stakeholders towards their business operations and overall corporate performance.

\section{Statement 2. Recognition of interdependence of efforts and rewards among stakeholders}

The study findings indicate that the vast majority of organisations recognise the interdependence of efforts and rewards among their stakeholders. A total of $74.0 \%$ agree (46.3\% "Agree" and $27.7 \%$ "Strongly agree") with the above statement, while only 3.6\% disagree and $22.4 \%$ "Somehow agree". The analysis demonstrates that most organisations recognise a stakeholder-centred approach that enhances teamwork. The recognition of the interdependence of stakeholders by various organisations confirms an "inclusive" management approach that is congruent with the principles of nature of ecosystems (Capra \& Pauli, 1995, Stead \& Stead, 2004), where all parts of the system are interconnected and depend on each other for common strategic survival. 


\section{Statement 3. Allocation of wealth to each stakeholder based on relative contributions}

Although organisations recognise the interconnectedness and inter-dependence of stakeholders, as discussed above, the results of the survey suggest that the need for equitable allocation of organisational wealth to stakeholders is not fully recognised by some organisations. The results show that $51.3 \%$ of the respondents agree that their wealth is allocated to each stakeholder based on the stakeholder's relative contribution to overall corporate performance, which is usually measured in the form of profitability. A total of $19.1 \%$ disagree with the statement, while $29.6 \%$ "Somehow agree". The findings demonstrate that some large corporations are still not engaged in equitable sharing of their resources with different stakeholders. The research findings suggest that some stakeholders do not benefit from the organisational wealth that they themselves have created. Therefore, the study findings suggest that corporate sustainability issues would be compromised when other stakeholders, such as the natural environment, are not properly rewarded.

\section{Statement 4. Receipt of sufficient stakeholder benefits for continued collaboration with organisations}

The study also aimed at establishing whether stakeholders receive sufficient funds to assure their continued collaboration with the organisation. The research findings show that a total of $69.4 \%$ agree (43.9\% "Agree" and $25.5 \%$ "Strongly agree") that their stakeholders are given sufficient benefits by the organisation to ensure that there is continued stakeholder collaboration within its operations. Only 8.6\% disagree, while $21.2 \%$ "Somehow agree" with the above statement. These research findings indicate that most organisations believe that sufficiency in the allocation of organisational wealth would be a motivating factor that ultimately enhances long-term cooperation and collaboration by different stakeholders. Such stakeholder collaboration would also promote long-term corporate performance and sustainability.

\section{Statement 5. Equitable distribution of wealth to stakeholders}

A majority of $69.7 \%$ agree that equitable distribution of their wealth to different stakeholders enables them to gain a continued good corporate reputation amongst stakeholders. Only $6.0 \%$ disagree and $24.3 \%$ "Somehow agree" with the statement. The research findings indicate that most organisations recognise the need to be equitable in resource allocations to their stakeholders. Organisations realise that a more equitable distribution of organisational wealth is likely to build a good reputation and create goodwill amongst stakeholders, which will in turn promote the sustainability of their business operations.

\section{Statement 6. Open disclosure of wealth distribution to stakeholders}

The statement was aimed at ascertaining whether or not organisations are open in distributing their wealth to different stakeholders through corporate reporting systems, as recommended by Szwajkowski (2000). A vast majority (80.9\%) of respondents agree (45.1\% "Agree" and 35.8\% "Strongly agree") that they deploy open resource allocation disclosure. Only $2.9 \%$ disagree, while $16.2 \%$ "Somehow agree" with the above statement. This analysis demonstrates that most organisations prefer open disclosure of resource allocations, which would ultimately encourage participation by different stakeholders in the business activities.

\section{Statement 7. Corruption practices}

This statement was aimed at determining whether or not corporate executives illegally and inequitably share organisational resources in a corrupt manner. The research findings show that a total of $78.3 \%$ agree (26.3\% "Agree" and $52.0 \%$ "Strongly agree") that their managers do not practise corruption, which deprives the very same stakeholders that an organisation is supposed to interconnect and depend upon. However, some respondents disagree (2.6\%) and others (19.1\%) only "Somehow agree" with the statement. Although the evidence is slim, the survey results reveal that corruption still occurs amongst managers in Malawi, which is against the teachings of the African socio-cultural setting under the Ubuntu philosophy. The Ubuntu philosophy advocates a spirit of solidarity, caring and sharing, where wealth should be distributed to all members, and not just to a very few undeserving and selfish individuals (Mbigi and Maree, 2005; Tutu, 2004).

\section{Statement 8. Payment of competitive prices to suppliers of inputs}

A vast majority of the organisations agree that they pay their suppliers fairly by offering competitive prices in the respective industries. A total of $83.0 \%$ agree (34.1\% "Agree" and $48.9 \%$ "Strongly agree"), while only $3.3 \%$ disagree and $13.6 \%$ "Somehow agree" with the statement. The research results indicate that most organisations not only recognise the significance of suppliers towards corporate activities as providers of inputs, but also that corporations 
allocate their wealth to suppliers by offering competitive prices as well. It is expected that continued fair trading practices with suppliers would motivate suppliers to continue providing the organisation with high quality inputs for long-term business sustainability.

\section{Statement 9. Financial support on educational projects}

The study also aimed at assessing the extent of which companies are engaged in the corporate social responsibility activities in the form of promoting education amongst the youth. Most of the companies indicate that they are involved in financially supporting educational projects as a basis for the continuity of business operations. A total of $72.6 \%$ agree with the statement. Only $12.9 \%$ disagree and $14.6 \%$ "Somehow agree". The study findings demonstrate that most organisations make a point of promoting education, thus encouraging the sustainability of future business operations and long-tern corporate performance. Unlike other factors of production, such as land and finance, a knowledgeable workforce should be considered a critical factor of production in the modern business environment (Drucker, 1993).

\section{Statement 10. Responsibility for direct social problems}

The research findings also indicate that most companies take direct responsibility for the social problems that they cause in the course of their operations. A majority of $67.1 \%$ agree, while $14.6 \%$ disagree and $18.4 \%$ "Somehow agree". The figures from the analysis indicate that issues of corporate social responsibility are still in transition, as some corporations still do not take on direct social responsibility for the effects that they have caused. These research findings are pertinent to the disclosure of social impact in corporate reports, as recommended by the King III Report (Institute of Directors in Southern Africa, 2009:109).

\section{Statement 11. Reservation of funds for natural environmental (ecological) preservation projects}

A total of $45.8 \%$ of the respondents indicate that their organisations reserve funds for the preservation of the natural environment, whilst $28.9 \%$ do not. Out of the respondents, $25.3 \%$ indicate that they "Somehow agree" that their organisations allocate funds towards natural environmental projects. These research findings demonstrate that issues of environmental preservation and protection are in transition, as many organisations are still not putting much emphasis on the issue of environmental protection. These study findings are consistent with those in Statement 3 which suggests that other critical stakeholders, such as the natural environment, are not properly rewarded. This finding is worrying, because the sustainability of current and future businesses and generations depends on how organisations conserve the natural environment today. The protection of the natural environment would improve the likelihood of the continued provision of many raw materials and other inputs for production, which is a fundamental facet in the conceptual framework.

\section{Statement 12. Contribution to the welfare of the society}

Generally, the vast majority of respondents indicate that their organisations contribute substantially towards the overall welfare of the local society. A total of $79.2 \%$ agree (41.1\% "Agree" and $38.2 \%$ "Strongly agree") with the above statement. Only $8.6 \%$ disagree and $12.12 \%$ "Somehow agree". Whilst the majority of the respondents' organisations recognise the presence of local communities through their contributions, the overall analysis indicates that there are still some corporations that are not ploughing back into the local communities in which they operate. Within the framework of the King III Report's recommendations (Institute of Directors in Southern Africa, 2009:109), one would expect the majority of companies to adhere to the provisions of good corporate governance and duly report the social and environmental sustainability together with an economic element in their corporate reports.

The research findings reveal that corporate conscience provide insights regarding critical issues that govern the allocation and sharing of organisational wealth to participating stakeholders of an organisation. The analysis of the twelve statements under the corporate conscience theme is summarised in Table 1. 
Table 1. Statistical summary of the univariate analysis on the questionnaire statements

\begin{tabular}{|c|c|c|c|c|c|c|c|c|}
\hline & \multirow{3}{*}{ Statement } & \multicolumn{6}{|c|}{ Rating scale (\%) } & \multirow{3}{*}{$\frac{\text { Mean }}{\mu}$} \\
\hline & & \multirow{2}{*}{$\begin{array}{l}\text { Strongly } \\
\text { Disagree }\end{array}$} & \multicolumn{3}{|c|}{ Somehow } & \multirow{2}{*}{$\begin{array}{l}\text { Strongly } \\
\text { Agree }\end{array}$} & \multirow{2}{*}{ TOTAL } & \\
\hline & & & Disagree & Agree & Agree & & & \\
\hline & $\begin{array}{l}\text { We recognise the interdependence of } \\
\text { relationships of our stakeholders }\end{array}$ & 0.0 & 0.0 & 8.8 & 45.1 & 46.1 & 100 & 4.4 \\
\hline 2. & $\begin{array}{l}\text { We recognise the interdependence of efforts and } \\
\text { rewards among our stakeholders }\end{array}$ & 0.0 & 3.6 & 22.4 & 46.3 & 27.7 & 100 & 4.0 \\
\hline 3. & $\begin{array}{l}\text { Organisational wealth is allocated to each } \\
\text { stakeholder based on their relative contributions } \\
\text { towards the overall corporate performance }\end{array}$ & 3.6 & 15.5 & 29.6 & 30.1 & 21.2 & 100 & 3.5 \\
\hline 4. & $\begin{array}{l}\text { All stakeholders receive sufficient benefits to } \\
\text { assure their continued collaboration with our } \\
\text { organisation }\end{array}$ & 0.7 & 8.6 & 21.2 & 43.9 & 25.5 & 100 & 3.8 \\
\hline 5. & $\begin{array}{l}\text { Equitable distribution of organisational wealth to } \\
\text { our stakeholders enables us to gain continued } \\
\text { corporate reputation }\end{array}$ & 1.9 & 4.1 & 24.3 & 48.4 & 21.2 & 100 & 3.8 \\
\hline 6. & $\begin{array}{l}\text { We are open in disclosing wealth distribution to } \\
\text { our stakeholders through corporate reporting }\end{array}$ & 1.9 & 1.0 & 16.2 & 45.1 & 35.8 & 100 & 4.1 \\
\hline 7. & $\begin{array}{l}\text { Our managers do not practise corruption that } \\
\text { deprives our valuable stakeholders }\end{array}$ & 0.0 & 2.6 & 19.1 & 26.3 & 52.0 & 100 & 4.3 \\
\hline 8. & $\begin{array}{l}\text { We pay our suppliers fairly by offering } \\
\text { competitive prices in the industry }\end{array}$ & 0.0 & 3.3 & 13.6 & 34.1 & 48.9 & 100 & 4.3 \\
\hline & $\begin{array}{l}\text { We are involved in financially supporting } \\
\text { educational projects for our future business } \\
\text { operations }\end{array}$ & 2.4 & 10.5 & 14.6 & 40.8 & 31.7 & 100 & 3.9 \\
\hline & $\begin{array}{l}\text { We take direct responsibility for social problems } \\
\text { that we have caused }\end{array}$ & 2.6 & 11.9 & 18.4 & 32.5 & 34.6 & 100 & 3.8 \\
\hline & $\begin{array}{l}\text { Our organisation reserves funds for natural } \\
\text { environmental (ecological) preservation projects }\end{array}$ & 5.3 & 23.6 & 25.3 & 30.8 & 15.0 & 100 & 3.3 \\
\hline & $\begin{array}{l}\text { We contribute substantially to the overall welfare } \\
\text { of the society }\end{array}$ & 2.4 & 6.2 & 12.2 & 41.1 & 38.2 & 100 & 4.1 \\
\hline
\end{tabular}

$\mathrm{N}=419$

The Table 1 above indicates that Statement 1: "We recognise the interdependence of relationships of our stakeholders" has the highest mean $(\mu=4.4)$ on the response ratings seconded by Statement 7: "Our managers do not practise corruption that deprives our valuable stakeholders" and Statement 8: "We pay our suppliers fairly by offering competitive prices in the industry" both with a mean $(\mu=4.3)$.

Further analysis of the above table shows that Statement 11: "Our organisation reserves funds for natural environmental (ecological) preservation projects" with a mean $(\mu=3.3)$ and Statement 3: "Organisational wealth is allocated to each stakeholder based on their relative contributions towards the overall corporate performance" with a mean $(\mu=3.5)$ are registering the lowest response ratings. Statement 11 hinges on issues to do with the protection of the natural environment which is a hot issue in the modern management systems today. That there is no ample equitable allocation of organisational wealth to the participating stakeholders which should also be worrisome as this would negatively affect future corporate performance of various organisations in Malawi. The detailed analysis indicates that the most neglected stakeholders are the natural environment and the community which are being highlighted more by the modern integrated reporting systems under the good corporate governance practices (Institute of Directors in Southern Africa, 2009).

Overall, all the twelve statements show means that are above average $(\mu>3.0)$ signifying the above-average rankings that organisations give to issues surrounding corporate conscience and also good corporate governance in Malawi which is a prerequisite for better corporate performance. 


\section{Conclusion}

The contemporary business environment demands that business executives of various companies run their operations with their stakeholders in mind as such stakeholders play critical roles in sustaining operations of any organisation. The understanding of stakeholder interfacing with an organisation and other stakeholders is instrumental in that every organisation is engaged in a series of complex activities involving different constituents that are linked and work together as a team for the ultimate organisational success and sustainability.

The research findings have revealed that most business executives working in Malawian companies recognise the vital roles that different stakeholders play for the success and sustainability of their operations. This is revealed in that all recognise the interdependence of relationships of their stakeholders. The managers also accept that there is interdependence of effort and rewards among stakeholders. This is crucial for any company as it entails that its very survival depends on the actions of these interrelated stakeholders. It has also been established in this study that most managers accept and acknowledge that stakeholders receive sufficient benefits to ensure continued collaboration. Such corporate conscience approach entails continued operations of the companies for better corporate performance.

Further, companies support educational projects, take responsibility for social problems that they have caused and that they contribute substantially to the overall welfare of the society. However, a smaller percentage of respondents admit that they reserve funds for natural environmental projects which are a critical component of company's future sustainability programmes. The research findings further suggest that issues of preserving natural environments in trying to address climate change concerns are new and are in the transitional stage in Malawi.

Therefore, the new phenomenon of corporate conscience takes cognisance of the fact that corporations have to have that conscience in the way they treat and reward their stakeholders that are constantly interacting with an organisation and are involved in perfecting sustainable corporate performance. Corporate conscience goes beyond the laid-down codes under corporate governance as the former has to come from an inside conviction of an organisation about the treatment and equitable rewarding of deserving stakeholders. The realisation that corporate performance is hinged on contributions by several players called stakeholders is very critical towards sustainable corporate performance.

The researchers feel that the study findings will facilitate the change of mindset by many business executives on issues to do with wealth creation and commensurate distributions to various stakeholders in the most equitable manner; facilitate the design and change in accounting and auditing principles and practices to serve the said challenges; facilitate the review and design of best corporate planning and performance measurement systems; review and design of government and industrial policies and regulations; and change of approaches in academic and business research. Of significance by all business executives is that recognition that every organisation has to be run on the premise of recognising the interconnectedness and relationships of corporate activities and the rewarding of the concerned stakeholders in the best way possible.

\section{References}

Aaron, K.K. (2012). New corporate social responsibility models for companies in Nigeria's Delta region: What challenges for sustainability? Progress in Development Studies, 12(4), 259-273. http://dx.doi.org/10.1177/146499341201200401

Akomea, S.Y., \& Adusei, M. (2013). Bank recapitalization and market concentration in Ghana's banking industry: A Herfindahl-Hirschman Index analysis. Global Journal of Business Research, 7(3), 31-45.

Babbie, E., \& Mouton, J. (2007). The Practice of social research. Oxford University Press, Southern Africa: Cape Town.

Bendixen, M., Abratt, R., \& Jones, P. (2007). Ethics and social responsibility. Journal of Applied Management and Entrepreneurship, 12(1), 3-24.

Bryman, A., \& Bell, E. (2007). Business research methods. Oxford University Press: New York

Capra, F., \& Pauli, G. (eds.). (1995). Steering business toward sustainability. New York: United Nations University Press.

Carroll, A.B. (1979). Three-dimensional conceptual model of corporate performance. Academy of Management Review, 4(4), 497-505.

Chenhall, R.H. (2005). Integrative strategic performance measurement systems, strategic alignment of manufacturing, learning and strategic outcomes: An exploratory study. Accounting, Organizational and Society, 30, 395-422. http://dx.doi.org/10.1016/j.aos.2004.08.001 
Chilosi, A. (2012). Stakeholder protection, varieties of capitalism, and long-term unemployment. The European Journal of Comparative Economics, 9(2), 197-228.

Costello, A.B., \& Osborne, J.W. (2005). Best practice in exploratory factor analysis: Four recommendations for getting the most from your analysis. Practical Assessment, Research \& Evaluation, 10(7), 1-9.

Dillman, D.A. (2000). Mail and International Surveys: The Tailored Design Method. New York: Wiley.

Drucker, P.F. (1993). Post-capitalist society. New York: Harper Business.

Field, A. (2009). Discovering Statistics Using SPSS. London: SAGE.

Friedman, M. (1993). The social responsibility of business is to increase its profits. In Olen, J. \& Barry, V. (Eds.), Applying ethics (pp. 433-438). Belmont, CA: Wadsworth.

Hanafizadeh, P., \& Sorousha, M. (2008). A methodology to define strategic processes in organizations: An exploration study in managerial holding companies. Business Process Management Journal, 14(2), 219-227. http://dx.doi.org/10.1108/14637150810864943

Institute of Directors in Southern Africa. (2009). The King Report on Corporate Governance for South Africa. Parklands, Cape Town: IDSA.

Kelly, M. (2001). The divine right of capital. San Francisco: BerrettKoehler.

Khomba, J.K. (2011). Redesigning the Balanced Scorecard model: an African perspective. A PhD thesis. University of Pretoria, Pretoria.

Mbigi, L., \& Maree, J. (2005). Ubuntu: the spirit of African transformation management. Johannesburg: Knowledge Resources.

Morgan, G., Ryo, K., \& Mirvis, P. (2009). Leading corporate citizenship: governance, structure, systems. Corporate Governance, 9(1), 39-49. http://dx.doi.org/10.1108/14720700910936047

Nakano, C. (2007). The significance and limitations of corporate governance from the perspective of business ethics: towards the creation of an ethical organizational culture. Asian Business \& Management, 6, 163-178. http://dx.doi.org/10.1057/palgrave.abm.9200216

Rasche, A., \& Esser, D.E. (2006). From stakeholder management to stakeholder accountability: applying Habermasian discourse ethics to accountability research. Journal of Business Ethics, 65, 251-267. http://dx.doi.org/10.1007/s10551-005-5355-y

Saunders, M., Lewis, P., \& Thornhill, A. (2009). Research methods for business students. Prentice Hall:Edinburgh, England.

Smith, A. (1790). The theory of moral sentiments. Retrieved February 24, 2013, from http://www.econlib.org/library/Smith/smMS1.html

Stead, W.E., \& Stead, J.G. (2004). Sustainable strategic management. New Delhi: Prentice Hall.

Stovall, O.S., Neill, J.D., \& Perkins, D. (2004). Corporate governance, internal decision making, and the invisible hand. Journal of Business Ethics, 51, 221-227. http://dx.doi.org/10.1023/B:BUSI.0000033615.22269.e3

Szwajkowski, E. (2000). Simplifying the principles of stakeholder management: the three most important principles. Business and Society, 39(4), 379-396. http://dx.doi.org/10.1177/000765030003900403

Tsuno, N. (2003). Outlook and assignments of business ethics and corporate governance. In Nakamura, M. (Ed.), Business ethics and corporate governance: an international comparison (pp. 179-200). Tokyo: Bunshindo.

Tutu, D. (2004). God has a dream: a vision of hope for our future. London: Rider.

Welman, C., Kruger, F., \& Mitchell, B. (2005). Research methodology. Oxford University Press, Southern Africa: Cape Town. 